оскільки воно відповідає за свіжість продукту. Результати експериментальних досліджень свідчать про те, що за показником перекисного числа усі зразки печива не перевищують гранично допустимих значень, хоча деякі зразки мають строки зберігання, що перевищують встановлені стандартом. Це, мабуть, можна пояснити використанням антиоксидантів у складі досліджуваних зразків печива.

Результати визначення мікробіологічних показників печива свідчать про відсутність бактерій групи кишкової палички (у 0,1 г продукту), плісеневих грибів (у 1 г) і патогенних мікроорганізмів (в 25 г) протягом усього терміну зберігання.

Висновки. Отже, під час зберігання цукрового печива істотних погіршень органолептичних і фізико-хімічних показників його якості виявлено не було. Проте спостерігалося зниження якості печива деяких ТМ, яке зберігалося протягом терміну, що перевищував встановлений стандартом, за окремими показниками (поверхня, колір, вигляд у розломі). Мікробіологічний аналіз досліджуваних зразків цукрового печива показав, що всі зразки протягом передбаченого терміну зберігання відповідали за мікробіологічними показниками вимогам стандарту.

Література:

1. Наконечна А. В. Маркетингове дослідження ринку кондитерських виробів в Україні / А. В. Наконечна // Економіка і управління. - 2016. - № 3. С. 86-92.

2. Печиво. Загальні технічні умови : ДСТУ 3781-98. - [Чинний від 1999-0701]. - К. : Держстандарт України, 1999. - 14 с. - (Національний стандарт України).

Стаття відправлена: 28.03.2017 р. (C) Чуйко M.M., Назарько В.О.

\title{
ЦИТ: иа117-056
}

DOI: 10.21893/2415-7538.2016-05-1-056

УДК 673.523(006.83)

\section{ДОСЛІДЖЕННЯ ЯКОСТІ СМАЖЕНИХ КОВБАС}

Доманова О.В., Кізімович О. I.

Харківський торговельно-економічний інститут Київського національного торговельно-економічного університету, Харків, Отакара Яроша 8, 61045

Domanova O.V., Kizimovych O. I. RESEARCH OF QUALITY OF FRIED SAUSAGES

Kharkiv Institute of Trade and Economics of Kyiv National University of Trade and Economics, Kharkiv, Otakara Yarosha str. 8, 61045

Анотащія. В роботі представлені результати дослідження якості смажених ковбас за органолептичними показниками (консистенція, вигляд фариу на розрізі, смак $i$ запах, форма батонів, товарна відмітка батонів (в'язання)). За результатами досліджень встановлено, щзо зразки ТОВ 
«Дергачівський м'ясокомбінат», ПрАТ «Ольховський м'ясокомбінат», ПП «Циркунівський м'ясокомбінат» мають присмний смак, але не властивий для даного виду виробів, оскільки є більш ніжним та соковитим, щчо характерно для ковбас з м'яса птиці. Також ковбаси ПП «Циркунівський м'ясокомбінат» мають різко виражений запах копчення.

Ключові слова: смажена ковбаса, органолептичні показники, якість.

Abstract. In work results of research of quality of fried sausages on organoleptic are presented indicators (a consistence, a forcemeat kind on a cut, taste and a smell, the form of long loafs, a commodity mark of long loafs (knitting). By results of researches it is established, that samples LLC «Dergachevsky meat combine», PJE «Olhovsky meat combine», PE «Tsirkunovsky meat combine» have pleasant taste, but not peculiar for data products as it more gentle and juicy, that is characteristic for sausages from meat birds. Also sausages PE «Tsirkunovsky meat combine» have sharply expressed smell of smoking.

Key words: fried sausage, organoleptic indicators, quality.

Ветуп.

Ковбасні вироби - це продукти з м'ясного фаршу із сіллю і спеціями, в оболонці або без неї, піддані термічній обробці або ферментації до готовності для споживання. Вони характеризуються високою харчовою цінністю завдяки вдалому поєднанню високоякісної сировини, відповідній обробці, наявності широкого вибору продукції, яка задовольняє потреби різноманітних споживачів [1].

Смажені ковбаси випускають лише в натуральних оболонках. Вони виготовляються як на підприємствах м’ясної промисловості, так і в домашніх умовах. Іноді така ковбаса продається як напівфабрикат, і на прилавках іiі можна зустріти з позначкою «ковбаса для смаження». У готовому вигляді вона може називатися українською, домашньою, смаженою, запеченою.

В наш час смажені ковбаси $€$ одним 3 досить популярних продуктів харчування, їх асортимент стабільно збільшується. Для виробництва на підприємствах використовуються як державні нормативні документи (ДСТУ), так і власно розроблені (ТУ). Тому дослідження якості смажених ковбас $\epsilon$ цікавим та актуальним.

\section{Огляд літератури.}

Органолептична оцінка, яка проводиться за допомогою органів відчуття людини, найбільш давній та широко розповсюджений спосіб випробування якості харчових продуктів. Органолептичні методи швидко, об'єктивно та надійно дають загальне враження про якість продуктів.

Об'єктами дослідження були зразки смажених ковбас українських виробників (табл. 1).

Смажені ковбаси за органолептичними показниками повинні відповідати вимогам ДСТУ 4433:2005 «Ковбаси смажені. Загальні технічні умови» [2]. У смажених ковбас визначали наступні органолептичні показники: зовнішній вигляд, консистенцію, вигляд фаршу на розрізі, смак і запах, форму батонів, товарну відмітку батонів (в'язання). 
Таблиця 1

Дослідні зразки смажених ковбас

\begin{tabular}{|c|c|c|c|}
\hline $\begin{array}{c}\text { № } \\
\text { зразка }\end{array}$ & $\begin{array}{l}\text { Назва } \\
\text { ковбас }\end{array}$ & Виробник & Юридична адреса виробника \\
\hline 1. & $\begin{array}{l}\text { «Домашня } \\
\text { смажена» }\end{array}$ & $\begin{array}{l}\text { ПП «Новожанівський } \\
\text { м’ясокомбінат» }\end{array}$ & $\begin{array}{l}\text { Україна, 61157, м. Харків, } \\
\text { вул. Азовстальська,7. }\end{array}$ \\
\hline 2. & $\begin{array}{l}\text { «Домашня } \\
\text { смажена» }\end{array}$ & $\begin{array}{l}\text { ТОВ «Салтівський } \\
\text { м’ясокомбінат» }\end{array}$ & $\begin{array}{l}\text { Україна, 61176, м. Харків, } \\
\text { вул. Краснодарська, 171Б }\end{array}$ \\
\hline 3. & $\begin{array}{c}\text { «Домаш- } \\
\text { ня» }\end{array}$ & $\begin{array}{l}\text { ТОВ «Дергачівський } \\
\text { м’ясокомбінат», } \\
\text { ТМ «Перша столиця» }\end{array}$ & $\begin{array}{l}\text { Україна, } 62371, \text { Харківська } \\
\text { обл., с. Подворки, вул. } \\
\text { Свердлова, 47A }\end{array}$ \\
\hline 4. & $\begin{array}{l}\text { «Домаш- } \\
\text { ня» }\end{array}$ & $\begin{array}{l}\text { ПрАТ«Ольховський } \\
\text { м’ясокомбінат», } \\
\text { ТМ «ВдоВоль» }\end{array}$ & $\begin{array}{l}\text { Росія, } 403651 \text {, Волгоградська } \\
\text { обл., с. Ольховка, селище } \\
\text { Осинки, } 38\end{array}$ \\
\hline 5. & $\begin{array}{l}\text { «Закар- } \\
\text { патська» }\end{array}$ & $\begin{array}{l}\text { ПП «Циркунівський } \\
\text { м’ясокомбінат», } \\
\text { ТМ «Денвер» }\end{array}$ & $\begin{array}{l}\text { Україна, 62441, } \\
\text { Харківська обл., с. Циркуни, } \\
\text { вул. Кірова, 74А }\end{array}$ \\
\hline
\end{tabular}

За зовнішнім виглядом, консистенцією, виглядом фаршу на розрізі, формою батонів та товарною відміткою (в'язанням) всі натуральні зразки відповідають вимогам ДСТУ 4433:2005. Поверхня батонів чиста, суха, без плям, зламів та пошкоджень оболонок. Фарш рівномірно розподілений, відповідного кольору, без сірих плям та порожнин, шматочки розміром від 12 до 18 мм, без відхилень. Батони скручені у 4 кільця, перев'язані хрестоподібно, що за ДСТУ 4433:2005 характерно для «Української» смаженої ковбаси.

Зразки №3, №4 та №5 мають приємний смак, але не властивий для даного виду виробів, оскільки є більш ніжним та соковитим, що характерно для ковбас 3 м'яса птиці. Можливо допустити, що для виготовлення використовувалась невідповідна сировина 3 метою зниження собівартості продукції, оскільки м'ясо птиці є дешевшим, ніж свинина.

Зразок №5 за запахом не відповідає вимогам ДСТУ 4433:2005, оскільки має різко виражений запах копчення, замість аромату прянощів та часнику. Це свідчить про порушення технології виробництва, адже традиційна технологія виробництва не передбачає етапу копчення при виготовленні смажених ковбас. Даний виріб варто віднести до напівкопчених ковбас, оскільки їх процес виготовлення передбачає варіння, смаження, копчення.

Для більш об'єктивного визначення органолептичних показників використовували 9-ти балову шкалу згідно з ГОСТ 9959-91 «Продукты. мясные. Общие условия проведения органолептической оценки» [3].

Результати балової органолептичної оцінки дослідних зразків смажених ковбас наведено на рис. 1.

3 рис. 1. видно, що на першому місці знаходиться зразок №1, який в середньому отримав 6,5 балів, що характеризується оцінкою «дуже добре». На другому місці знаходиться зразок №2 3 кількістю балів 5,83 і оцінкою «вище середнього». Третє місце розділили зразки №3 і №4 - 4,67 бали, «вище 
середнього». На останньому місці знаходиться зразок №5 - 4,0 бали, «нижче середнього».

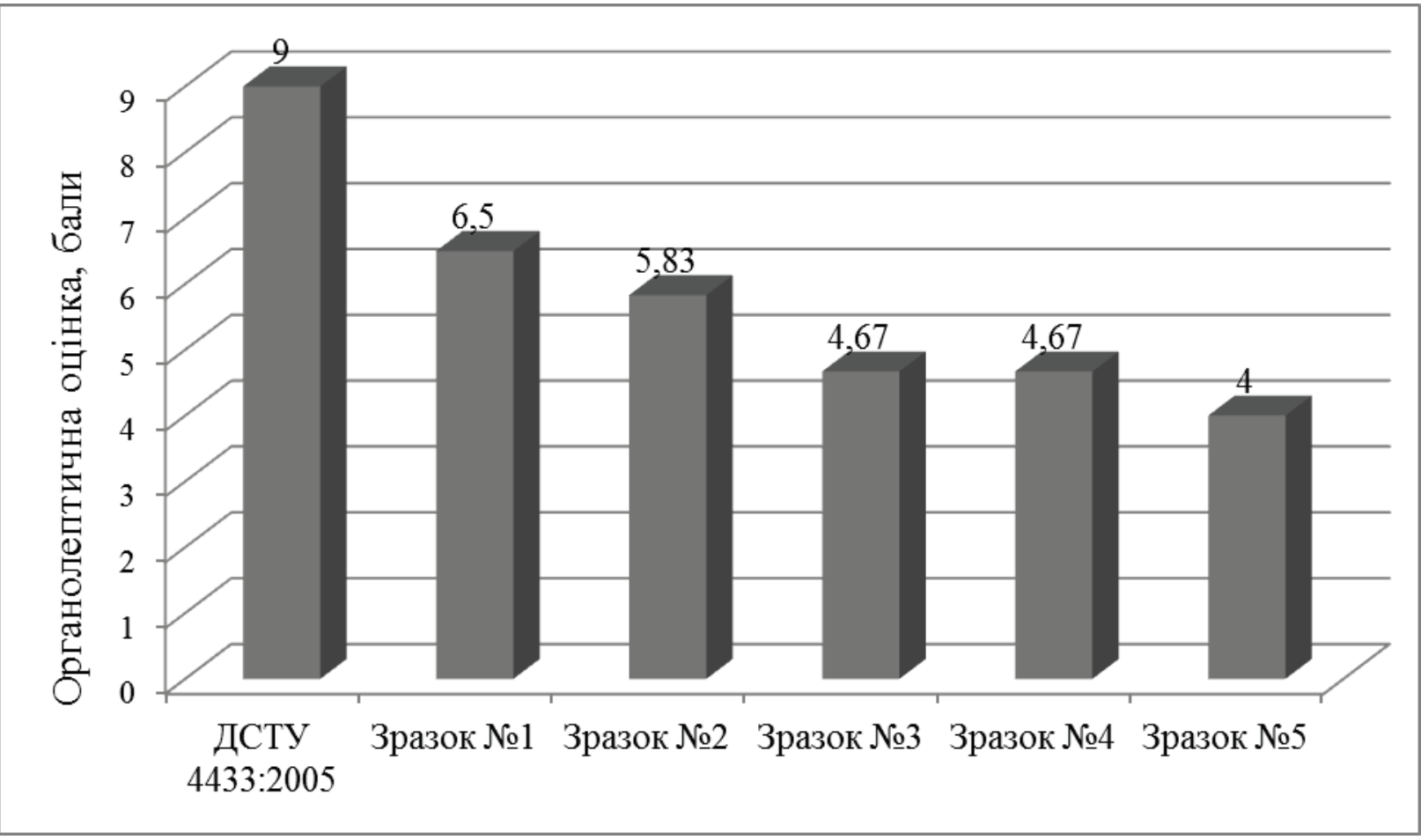

Рис. 1. Балова органолептична оцінка дослідних зразків смажених ковбас

Умовні позначення: зразок №1 - смажена ковбаса "Домашня смажена»,

ПП «Новожанівський м'ясокомбінат»; зразок №2 - смажена ковбаса «Домашня смажена»,

ТОВ «Салтівський м'ясокомбінат»; зразок №3 - смажена ковбаса «Домашня»,

ТОВ «Дергачівський м'ясокомбінат»,; зразок №4 - смажена ковбаса «Домашня», ПрАТ «Ольховський м'ясокомбінат»; зразок №5 - смажена ковбаса «Закарпатська», ПП «Циркунівський м'ясокомбінат».

Зразок №1 отримав найбільшу кількість балів за зовнішній вигляд і вигляд фаршу на розрізі (по 8 балів), найнижчу - за смак та консистенцію (є жорсткуватою) (по 5 балів).

Зразок №2 має гарний зовнішній вигляд, вигляд фаршу на розрізі та запах (по 7 балів), але жорсткувату консистенцію (4 бали).

Зразок №3 характеризується гарним зовнішнім виглядом (7 балів) та недостатньо вираженим смаком і соковитістю (по 3 бали).

Зразок №4 та зразок №5 отримали найбільшу кількість балів за досить гарний зовнішній вигляд і вигляд фаршу на розрізі (по 6 балів), найменшу зразок №4 за досить рихлу консистенцію (3 бали), а зразок №5 за погані недопустимі для смажених ковбас смак та запах (по 2 бали).

Висновки. За результатами органолептичної оцінки встановлено, що вимогам ДСТУ 4433:2005 відповідають смажені ковбаси ПП «Новожанівський м'ясокомбінат» та ТОВ «Салтівський м'ясокомбінат», також ці зразки ковбас отримали високу балову оцінку.

Література:

1. Сирохман I. В. Товарознавство м'яса і м'ясних товарів : навч. посіб. / 
I. В. Сирохман, Т. М. Раситюк. - К. : Граніт , 2006 - 382 с.

2. Смажені ковбаси. Загальні технічні умови : ДСТУ 4433:2005. - [Чинний від 2005-07-15] - К.: Держспоживстандарт України, 2006. - 14 с. - (Національні стандарти України).

3. Продукты мясные. Общие условия проведения органолептической оценки: ГОСТ 9959-91. - [Дата введения 1993-01-01]. - М.: Изд-во стандартов, 1992. - 14 с. - (Межгосударственный стандарт).

ЦИТ: ua117-088

DOI: 10.21893/2415-7538.2016-05-1-088

УДК 664.38

\section{Махинько В.Н., Соколовськая И.А., Землинская М.Д. ИННОВАЦИИ В ОЦЕНКЕ БЕЛКОВОЙ СОСТАВЛЯЮЩЕЙ ПИЩЕВЫХ ПРОДУКТОВ}

Национальный университет пищевых технологий,

Киев, Владимирская 68, 01601

Makhynko V.M., Sokolovska I.O., Zemlynska M.D. INNOVATIONS IN THE EVALUATION OF THE PROTEIN COMPONENT OF FOOD

National University of Food Technologies, Kyiv, Volodymyrska 68, 01601

Аннотащия. Белок является одним из важнейших и наиболее дефицитных пищевых компонентов. Поэтому совершенствование существующих рещептур и разработка новых продуктов с повышенной биологической ценностью является актуальной задачей для пищевой промышленности. Для проверки эффективности предпринятых мер следует иметь точные методы оценки. Лучше использовать расчетные методики, поскольку они не требуют значительных затрат времени и денег. В настоящее время две методики оценки белковой составляющей пищевых продуктов и рачионов являются общепринятыми и рекомендованными экспертами ФАO - PDCAAS и DIAAS. Расчет аминокислотного скора этими методами учитывает усвояемость белка или аминокислот, так что эти методы являются более точными. В статье представлены описания методик PDCAAS и DIAAS.

Ключевые слова: белок, аминокислота, усвояемость, биологическая ценность, расчет, PDCAAS, DIAAS.

Abstract. Protein is one of the most important and most scarce food components. Therefore improvement of existing products recipes and developing new products with increased biological value is the actual task for the food industry. To test the effectiveness of implemented activities should have precise methods of evaluation. It is better to use the calculation methods. Those methods do not require significant time and money. At present two methods of foods and diets protein component evaluating are generally accepted and recommended by FAO experts - PDCAAS and $D I A A S$. The calculation of the amino acid score by these methods take into account the digestibility of protein or amino acids so these methods are more accurate. The 